\title{
Strategic Analysis of International Competitiveness for Construction Firms in China
}

\author{
Shigang Yan $^{1}$ \\ ${ }^{1}$ Associate Professor, China Foreign Affairs University, Beijing, P.R.China \\ yanshigang@cfau.edu.cn
}

Key words: construction firms, China, strategy, international competitiveness

\begin{abstract}
As an important participant at the international construction market, Chinese construction firms (CCFs) are confronted with the tasks of keeping themselves competitive. The paper analyzed the current situation and challenges of CCFs at the international construction Market. To help construction firms maintain and improve their competitiveness, this research builds a conceptual model to investigate the relationship between core capability, competitive strategy and market entry mode strategy within CCFs.
\end{abstract}

\section{Introduction}

With the rapid development of the Chinese construction industry, increasing support from the government, and China's internationalization, Chinese construction firms (CCFs) have been given great opportunities in venturing abroad and acquiring wide-ranging experience, enhancing their knowledge and skills. Some CCFs have made significant achievements in the global construction market. The number of CCFs that have emerged in the Engineering News Record (ENR) Top 250 International Contractors list has increased from a mere 4 in 1992 to 65 in 2016 (ENR, 2017).

The rapid emergence of CCFs in international markets has generated much interest in their competitors around the globe as well as in researchers (Chen \&Orr, 2014; Co, 2014; Zhao et al., 2017). Although CCFs have had great achievements in recent years, their international market share is still relatively small compared to the more established contractors from advanced industrialized countries. Chinese contractors' share of the international market is still smaller in comparison with their competitors. The international revenue generated by the top 54 European construction firms accounted for $43.2 \%$ of all total international revenue received in 2016. International competitiveness must be improved significantly if they want to make a bigger foray into international markets. The purpose of this study is to understand the determinants of CCFs. Drawing on the resource-based view and industry organization approach, the study focuses on strategic analysis in affecting CCFs' international performance.

\section{Literature review}

The resource-based view focuses on the firm's resources and capabilities to understand business strategy and to provide direction to strategy formulation. Resources include financial resources, tangible resources and intangible resources (Barney, 1991). Through the internationalization process, firms gradually expand their business activities beyond their national authority and launch operations in other countries (Ahmad \& Kitchen, 2008). Resources and core capabilities are important for the internationalization of any firm. The presence of resources and capabilities could

\footnotetext{
${ }^{1}$ Corresponding author
} 
provide a firm the discretion or motivation (strategic choices) to pursue a strategy of internationalization thereby increasing its size and profitability. Moreover, a firm can develop new capabilities as they expand internationally. These new capabilities help the firm compete in the international market (Gaur et al., 2014).

Industrial organization approach examines the impact of environment on firm's competitive behavior and performance at the industry level. Porter (1980) adapted this paradigm to strategic management and examined existing firm's strategic decision to enter a new business. In the international context, CCFs have made significant progress in building up their competitiveness in recent years and become competitors to other overseas contractors in international construction markets Chinese contractors adopted competitive strategies especially in changing environment in order to achieve sustainable growth and profitability (Kaila, 2012). Zhao et al. (2017) analyzed the prevailing process of internationalization of top Chinese contractors and provided a strategic direction for their international construction market selection. Parsa et al. (2015) stated that Chinese construction firms continued to improve their international competitiveness by adopt competitive strategies in the international construction markets.

Through the internationalization process, firms gradually expand their business activities beyond their national authority and launch operations in other countries (Ahmad \& Kitchen, 2008). To expand its activities to the international market, a firm must adapt an appropriate form of entry that determines the firm's performance and survival in foreign markets (Pan \& Tse, 2000). The selection of an appropriate entry mode is crucial and affects the overall success of an investment. For different market entry modes, the resource commitment should be different, and the firms will possess different control power, but they have to face different level of risks. Generally, the greater the resource commitment, the higher the risk, but also the more control the firm has over its international operation.

\section{Development and challenges of CCFs at the international construction market}

\subsection{The development of CCFs at the international construction market}

CCFs have achieved significant milestones in the international market since 2000. They are actively involved in construction projects in more than 180 countries or regions. In 2000, there were 34 Chinese contractors listed at the ENR Top 250 International Contractors, and their total turnover was US\$ 17.5 billion. In 2000, CCFs gained nearly $80 \%$ of their total international revenue in Asia (Zhao, et al., 2017). It was far ahead the Middle East and Africa markets. In 2016, the gross contracting revenue of the 65 Chinese contractors reached US\$ 98.7 billion and accounted for $21.1 \%$ of the top 250 contractor's revenue (ENR, 2017). The Africa and Asia market shares of CCFs rose rapidly, up to about $56.2 \%$ and $31.8 \%$ respectively.

The types of international construction projects undertaken by CCFs can be categorized as follows: general building, transportation, power, petrochemical, manufacturing, sewage treatment, water supply, telecommunication projects, etc. (Zhao et al., 2017). In 2016, the top three types of works involving CCFs are general building, transportation and petrochemical projects. There is a trend from 2011 to 2016 towards more diversification in CCFs' construction business. General building works remain the biggest share. More projects involving high technology and financial requirements have been undertaken, including large industrial manufacturing, power, water supply and telecommunication works.

\subsection{Challenged faced by CCFs at the international construction market}

The potential challenge to CCFs can be attributed to four aspects. First, market entry barriers of some AICs still persist despite being lowered after China's WTO entry. Such entry barriers deter CCFs from the geographical expansion into these markets. Second, even in NICs and LDCs, the 
trend of international construction is towards greater emphasis on financing, technology and sophisticated project management. International contractors from AICs are naturally favored over CCFs as the former possess such advantages. Third, while painstakingly competing with their international rivals, CCFs are also competing among themselves in foreign markets with increasing internationalization. CCFs have yet to establish a cluster approach to compete internationally. The coordination from Chinese government agencies is found to be lacking. The outcome is that CCFs' international rivals will benefit from their internal competition.

\section{A theoretical model to analyze international competitiveness of CCFs}

The concept of international competitiveness has received much academic attention and has become well established in the literature (Chen \&Orr, 2014; Co, 2014; Kaila, 2012; Parsa et al.,2015; Zhao et al., 2017). Regardless of which theoretical perspective is represented, there is a general agreement that the purpose of strategic competitive activity in the firm is to achieve a sustainable competitive advantage, and thereby enhance a business’ performance.

\subsection{Core capability and international competitiveness}

With the globalization of the world economy, construction markets in most countries are gradually opening to foreign contractors. International contractors from different countries tend to adopt different strategies to compete internationally. To achieve success in the international construction market, CCFs need to upgrade their organizational capabilities through operations in new countries and markets. Cheah et al. (2007) identified seven strategic fields and two internal mechanisms of organization for large global engineering and construction firms. These issues exist at the corporate level and are embedded in the very lifeblood of the organization, and hence reflect the corresponding firm-specific resources and capabilities. Chen \& Orr (2014) analyzed the mechanisms of Chinese contractors' entry into Africa and stated Chinese contractors' performance in Africa in terms of business revenue actually hinges upon availability of financing sources and availability of natural resources. Gaur et al. (2014) identified three critical resource/capability variables, namely international experience, marketing and technological capabilities to study the competitive advantage of Chinese firms in the international market. Thus, it expects CCFs with a wide variety of capabilities to have a broader range of possible actions and enhance CCFs' international performance.

\subsection{Competitive strategy and international competitiveness}

The business environment within international construction market is very volatile. Competition from new entrants, social reforms, technological advancement and globalization pose major challenges of growth of this industry. Carpano et al. (1994) studied generic competitive strategies in the international context from two major dimensions: segment differentiation and geographical scope. They also highlighted the importance of cost leadership and differentiation strategies. Pheng et al. (2004) suggested that the relatively low cost of construction machinery, material and equipment from China facilitates the reduction of the bidding price for CCFs. Kaila (2012) focused on the competitive strategies adopted by Chinese contractors in Kenya and stated that the most practiced competitive strategies by Chinese adopted were cost leadership and differentiation strategy. Prasa et al. (2015) found that the international competitiveness of CCFs continued to improve due to relatively low costs and resulting competitive bidding prices. Thus, it expects CCFs to have a broader range of possible actions and rely heavily on developing competitive strategy in order to be sustainable in the international construction market. 


\subsection{Market entry strategy and international competitiveness}

It is an ambitious task to link market entry strategies with their influence on subsequent performance. Gunhan (2003) stated that some entry modes provided better performance than other modes. market entry strategy could have important implications for firm's performance. Specifically, it was found that the comparative performance of the three entry modes - wholly-owned subsidiary, JV and M\&A was contingent on the industry of entry and the associated demands for local content. Chen \& Hu (2002) revealed that wholly-owned subsidiaries are more likely to be chosen than EJVs when MNEs expand into markets with high regional and industrial growth; and they are also more likely to be chosen than CJVs when the investments involve proprietary products or where the cultural distance is large between the home and host country markets. CCFs adopting JVs benefit from savings in production costs, risk sharing with local partners, acquiring knowledge of host markets, and securing future growth opportunities. As sophisticated contracting has become one of the significant trends of international construction. The sophistication level of contracting modes directly influences the rivalry intensity among international construction participants (Leiringer, 2006).

\section{Conclusions}

The conceptual model presented herein was a generic framework that allowed industry practitioners and academic researchers to understand, sustain and extend the international competitiveness of CCFs. The conceptual model implied that CCFs' international competitiveness depends upon the identification of appropriate strategy and industry structure as well as developing and creating core capability in order to exploit opportunities and neutralize the threats presented by competition. Based on the conceptual model, future research will put forward hypotheses which are built up to test patterns of core capability, competitive strategy and market entry mode on international performance of Chinese CCFs.

\section{Acknowledgment}

The research is supported by Fundamental Research Funds for the Central Universities (No. 3162014ZYKC03).

\section{References}

[1] Ahmad, S.Z. Kitchen, P.J. International expansion strategies of Malaysian construction firms: Entry mode choice and motives for investment [J]. Problems and Perspectives in Management, 2008 6(3) 15-23.

[2] Barney, J.B. Firm resources and sustained competitive advantage [J]. Journal of Management, 1991 (17) 99-120.

[3] Cheah, C.Y.J., Kang, J., Chew, D.A.S. Strategic analysis of large local construction companies in China [J]. Construction Management and Economics, 2007 25(1) 25-38.

[4] Chen, C. Orr, R.J. Chinese contractors in Africa: home government support, coordination mechanisms and market entry strategies [J]. Journal of Construction Engineering and Management, 2014 135(11)1201-1210.

[5] Co, C.Y. Chinese contractors in developing countries [J].Review of World Economics, 2014 150(1) 149-171.

[6] Gaur, A.S., Kumar, V., \& Singh, D. Institutions, resources, and internationalization of emerging economy firms[J]. Journal of World Business, 2014 49(1) 12-20. 
[7] Carpano, C., Chrisman, J.J., \& Roth, K. International strategy and environment: An assessment of the performance relationship[J]. Journal of International Business Studies, 1994 25(3) 639-656.

[8] Cheah, C.Y.J., Kang, J., \& Chew, D.A.S. (Strategic analysis of large local construction companies in China [J]. Construction Management and Economics, 2007 25(1) 25-38.

[9] Chen, H., Hu, M.Y.. An analysis of determinants of entry mode and its impact on performance[J]. International Business Review, 2002 (11)193-210.

[10] Engineering News Record (ENR). The top 225 international contractors [DB/OL]. Available: http://www.enr.com/ext/resources/Issues/National_Issues/2017/ 08-Aug/21-Aug/08212017_Top250_full.pdf, 2017.

[11] Gunhan, S. Foreign market entry decision model for construction companies [D]. PhD thesis, Illinois Institute of Technology, USA, 2003.

[12] Kallia ,M. A. Competitive strategies adopted by Chinese firms in the building and construction industry in Kenya [D], PhD thesis, University of Nairobl, 2012.

[13] Leiringer, R. Technological Innovation in PPPs: Incentives, opportunities and actions[J]. Construction Management \& Economics, 2006 24(3) 301-308.

[14] Pan, Y., \& Tse, D.K. The hierarchical model of market entry modes [J]. Journal of International Business Studies, 2000 31(4) 535-554.

[15] Parsa, A., Huston, S., Kashyap, A., Li, P. The international competitiveness of Chinese construction firms [C]. European Real Estate Society (ERES) Conference, 24-27th June, 2015, Istanbul, Turkey.

[16] Pheng, L. S., Jiang, H. B., Christopher, H. Y. L. A comparative study of top British and Chinese international contractors in the global markte [J]. Construction Management and Economics, 2004 (22)717-731.

[17] Porter, M.E. (1980). Competitive Strategy: Techniques for Analysing Industries and Competitors [M]. New York, NY:Free Press.

[18] Zhao, Z., Yao, J, Tang C. Chinese Contractors in the International Market: Business Distribution and Competitive Situation [C]. Proceedings of the 20th International Symposium on Advancement of Construction Management and Real Estate, 2017. 